\title{
Economic feasibility study of a fuel cell-based combined cooling, heating and power system for a data centre
}

\author{
Suat Sevencan*, Göran Lindbergh, Carina Lagergren, Per Alvfors \\ KTH Royal Institute of Technology, Department of Chemical Engineering and Technology, Teknikringen 42, SE-100 44 Stockholm, Sweden
}

\section{A R T I C L E I N F O}

\section{Article history:}

Received 15 October 2015

Received in revised form 30 October 2015

Accepted 4 November 2015

Available online 22 November 2015

\section{Keywords:}

Fuel cell

Combined cooling heating and power

Data centre

Feasibility

\begin{abstract}
A B S T R A C T
The energy use of data centres is increasing as the data storage needs increase. One of the largest items in the energy use of these facilities is cooling. A fuel cell-based combined cooling, heating and power system can efficiently meet such a centre's need for cooling and in the meantime generate enough electricity for the centre and more. In this paper the economic feasibility of a fuel cell-based combined cooling, heating and power system that meets the energy demands of such a facility is investigated using operational data from an existing data centre in Stockholm, Sweden. The results show that although the system is not feasible with current energy prices and technology it may be feasible in the future with the projected changes in energy prices.
\end{abstract}

(c) 2015 Elsevier B.V. All rights reserved.

\section{Introduction}

As the world moves from paper to digital media the number of data centres increases rapidly [1]. Almost every sector, in one way or another, is dependent on one or more such centres. With the increase of our dependence on these centres, the electricity use of these centres increases. Between the years 2000 and 2005, 80\% of the growth in the world's electricity use may be attributed to the growth in number of servers, data centres and digital storage [2]. Of the electricity used in commercial buildings in the US $36.5 \%$ is for cooling, ventilation and refrigeration [3]. In their Clean Computing report, Uptime Institute estimates that $2 \%$ of all greenhouse gas emissions per year comes from IT and related technologies [4]. Cooling systems are one of the largest components of electricity use in such facilities, and they constitute $25-50 \%$ of all electricity used in servers [5-7].

As the efficiency of prime movers at low power increases by technological improvements and/or innovations the focus of electricity generation is moving from central to distributed generation. Co-location of the power generation system and the load brings a substantial decrease in transmission and distribution losses of electricity and savings on infrastructure. Powering such facilities with distributed generation brings many advantages such as flexibility against fuel prices, reliability and savings on distribution and transmission losses [8-11].

\footnotetext{
* Corresponding author. Tel.: +468 7906505 .

E-mail address: sevencan@kth.se (S. Sevencan).
}

Another advantage of co-location of supply and demand is the possibility to use the waste heat from electricity generation. Utilizing waste heat from a prime mover is called co-generation, a well-known and well-used concept worldwide. Combined cooling, heating and power (CCHP) is a derivation of co-generation that uses waste heat in a thermally driven cooling system, increasing the efficiency further. Since cooling is one of the biggest items in energy use, CCHP can provide many advantages such in economics, energy efficiency, environmental impact and reliability [7]. Conventionally, these facilities use grid electricity to power their computers and electrical cooling technologies to cool them. Fig. 1 illustrates a comparison between CCHP (right) and conventional methods (left) meeting a data centre's energy needs.

Meeting energy needs with a conventional system is not as efficient as with a CCHP system; hence more primary fuel will be needed. Fig. 2 shows a possible Sankey energy flow diagram of a comparison of CCHP and conventional separate generation of electricity, heat and cooling $[7,12,13]$. A certain amount of the total load corresponds to electrical energy, $37.5 \%$ in this example. The remaining parts, heating and cooling, may in an integrated system be supplied by the prime mover as well, resulting in a much higher overall efficiency.

Fuel Cells (FC) are electrochemical devices that convert chemical energy in hydrogen into electrical energy without combustion. The FC system investigated in this study is a Molten Carbonate Fuel Cell (MCFC). MCFCs operate at $500-700{ }^{\circ} \mathrm{C}$ and have $\mathrm{CO}_{3}{ }^{2-}$ as mobile ions. The high temperature makes them good prime movers for applications that can utilize high temperature waste heat such as 


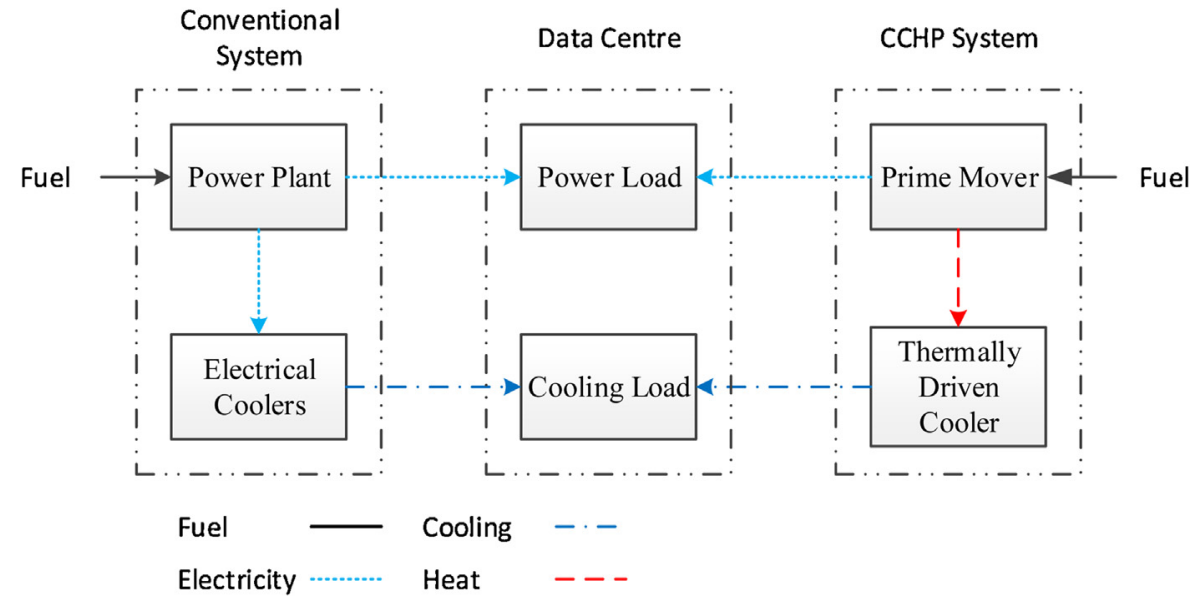

Fig. 1. Comparison of conventional system and CCHP, meeting a data centre's energy needs (based on [7]).

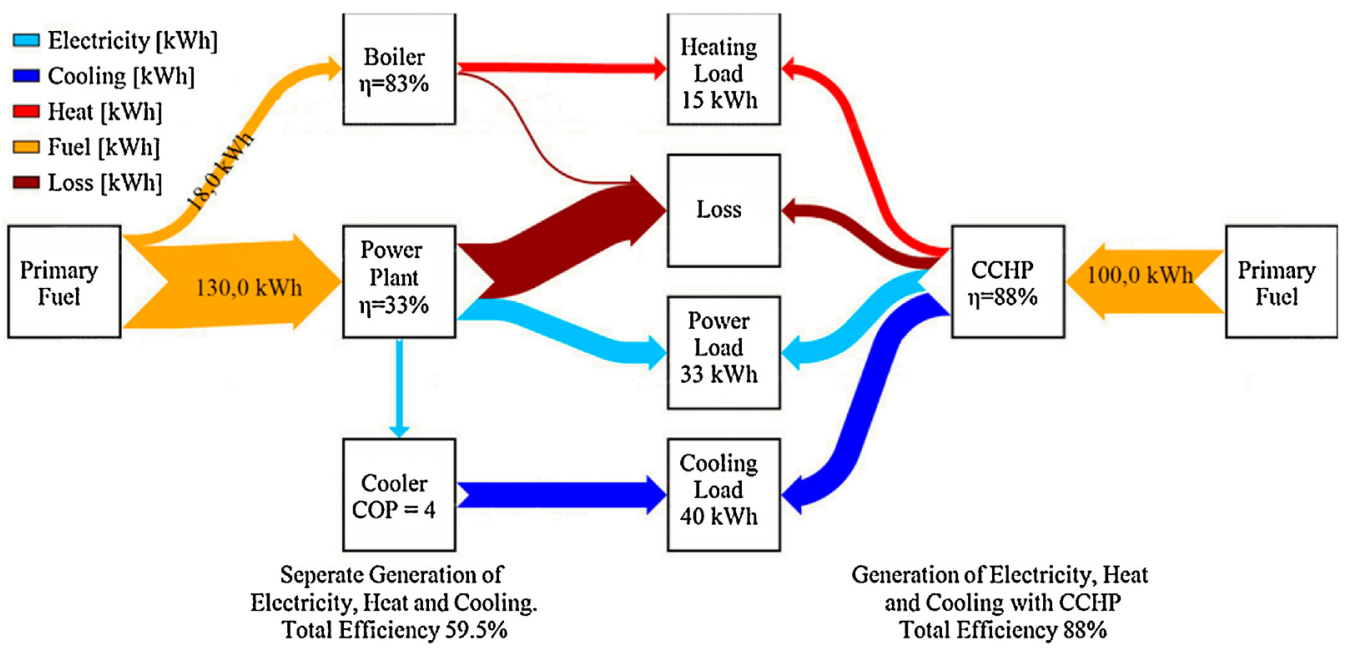

Fig. 2. Sankey energy flow diagram comparing CCHP to conventional separate generation (based on [13]).

co-generation and CCHP. Fig. 3 illustrates the working principle of an MCFC.

The interest in the IT sector in FCs is growing every day [14,15]. With their high electrical efficiency, low noise and low emissions, FCs are important prime movers for CCHP and distributed generation applications [16]. Since an FC does not have moving parts, there are less scheduled outages which increases the reliability. The International Energy Agency identifies FC-based distributed generation as an important technology that may provide security against power outages [10].

The thermally driven cooling system studied in this work is based on the LiBr (solvent)-water (refrigerant) absorption cycle. Fig. 4 shows the basic working principle of the absorption cycle, which is similar to the conventional vapour compression cycle; the only difference is that the refrigerant vapour compression is done with the absorber and a pump instead of a mechanical compressor.

The system works via the following principle: The heat evaporates the refrigerant in the generator, which then flows to the condenser. Condensed refrigerant then goes through an expansion valve into the evaporator where it takes heat from a chilled water circuit and evaporates again. The refrigerant vapour then goes into the absorber where it is sprayed with the refrigerant weak

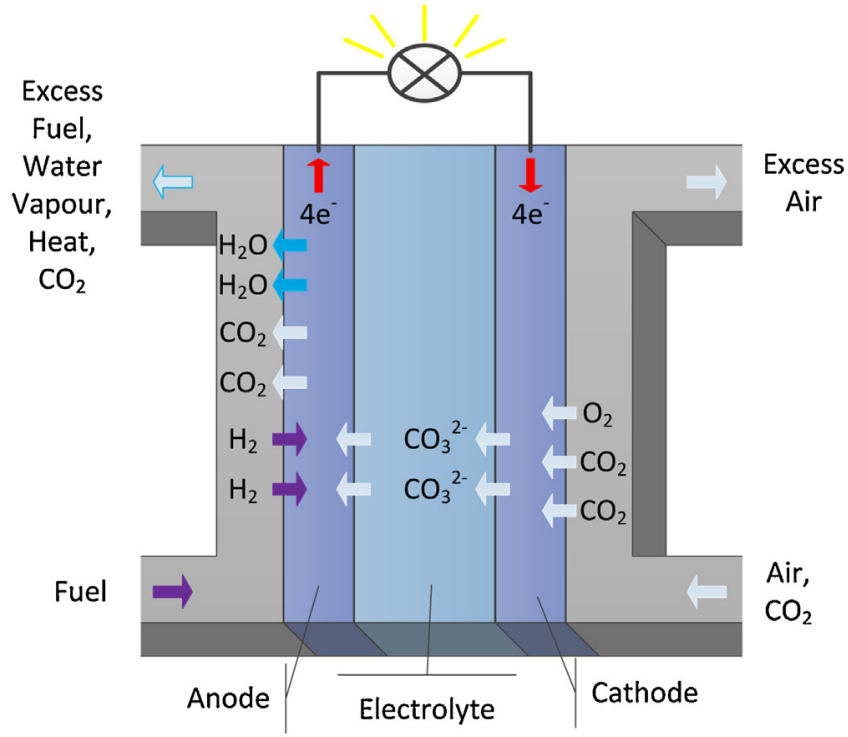

Fig. 3. Working principle of molten carbonate fuel cells. 


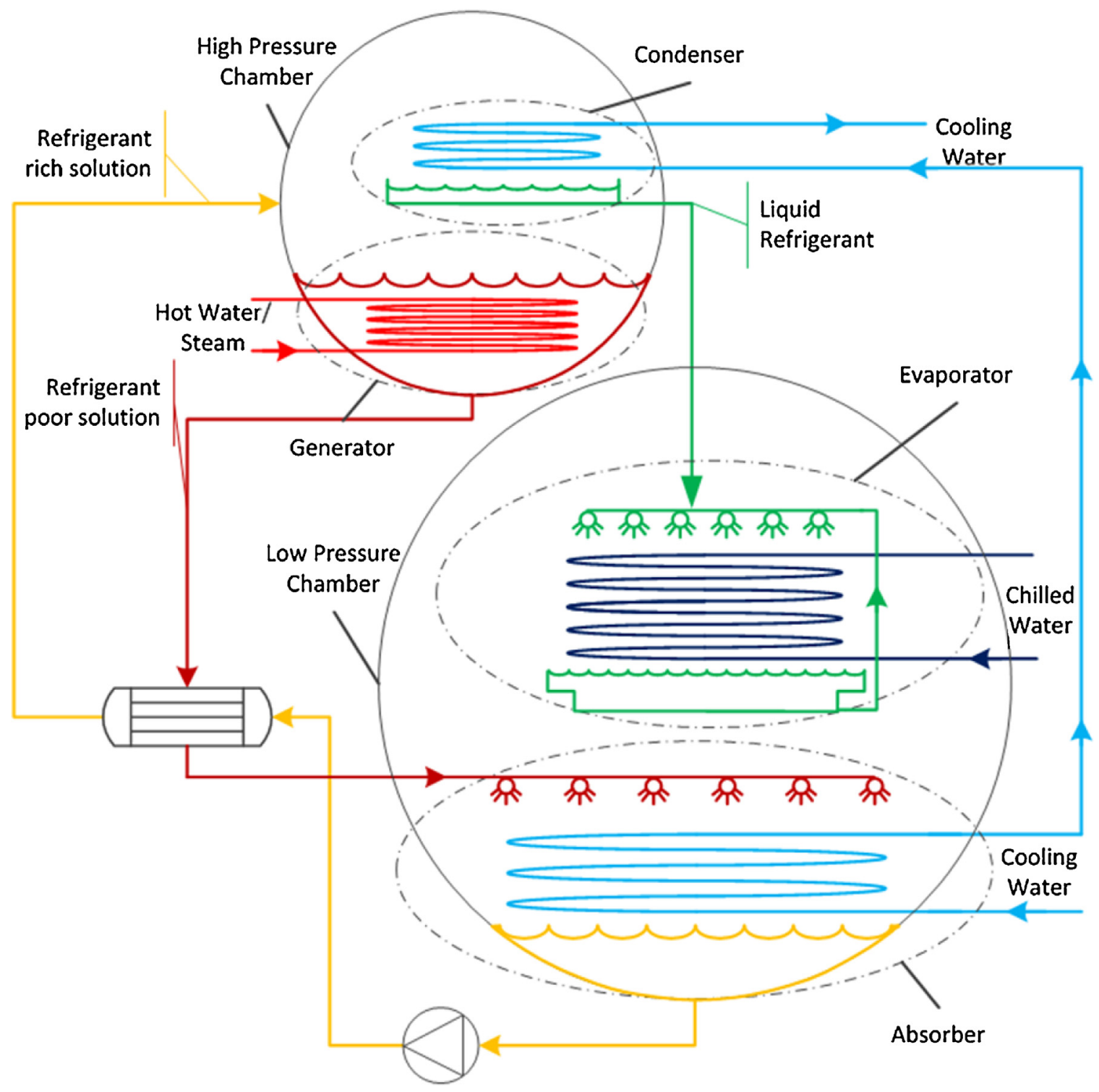

Fig. 4. Basic working principle of absorption chillers (based on [17]).

solution coming from the generator absorbing it. This refrigerant rich solution is then pumped back to the generator.

The cooling capacity of an absorption system may be improved by addition of an extra condenser-generator set. A system with two condenser-generator sets (low temperature and high temperature) is called a double effect absorption cooler. As the number of condenser-generator sets increases so will the coefficient of performance of the system, but this brings a demand for higher temperature heat. This change in demand is important especially when these systems are used to utilize waste heat. The temperature of the exhaust gas is the criterion for the choice of a single or double effect absorption system.

There are a number of studies on the general energy efficiency of data centres and their cooling alternatives in the literature [18-25]. Schmidt et al. [26] looked into powering and cooling a modern centre via co-generation. They concluded that the payback period of such a system is grossly dependent on natural gas and electricity prices. Xu and Qu [7] presented a comprehensive performance assessment of a CCHP system to the meet power demands of such a centre. They concluded that the stable nature of the demand and low power-to-cooling-demand ratio makes these centres a good match for CCHP use; to make CCHP feasible for data centre use the electricity price per MWh should be higher than that of natural gas. They further concluded that CCHP, for the case they were investigating, may bring an operational cost saving of up to 54\%. The literature on FC-powered data centres also focuses on meeting electrical load with FCs [27-32]. Riekstin et al. analysed the possibility of powering a centre with a FC in each rack. With conservative projections they concluded that it is possible to reach more than $20 \%$ cost reduction [33]. Zhao et al. tested a $10 \mathrm{~kW}$ in-rack fuel cell system with different loads. They concluded that it is possible to eliminate the grid connection and internal power distribution systems on the data centre [34]. They also investigated the possibility of data centre powering of a server rack with a $10 \mathrm{~kW}$ in-rack FC. They concluded that this system can achieve 53\% efficiency [35]. The only FC-CCHP study was made by Guizzi and Manno. They modelled a FC-CCHP system powering a centre with constant power and cooling loads. The system was estimated to make a $47 \%$ cost reduction, above $20 \%$ primary fuel use reduction and more than $20 \% \mathrm{CO}_{2}$ emission reduction [36].

This paper's aim is to investigate the economic feasibility of a FC-based CCHP system that meets the energy demands of a centre 
using operational data from an existing data centre in Stockholm, Sweden.

\section{Methodology}

The electrical and cooling loads that are used for the calculations are the electricity and cooling use of the Parallel Data Centre (PDC) at KTH-Royal Institute of Technology, Stockholm for the year 2012 [37]. The centre has seven different super computers, and a cloud server. In 2012 the centre used a monthly average of $936 \mathrm{MW}$ h as electricity and $865 \mathrm{MW}$ h for cooling for these systems. The centre's electricity comes from the Swedish grid and the cooling is mainly uses district cooling. There are also backup systems; two diesel generators with a total of $800 \mathrm{~kW}$ rated power for electricity backup; compressor cooling chillers and a tap water-based system with a cooling power of $500 \mathrm{~kW}$ and $400 \mathrm{~kW}$, respectively, for cooling backup [37]. Using a FC-CCHP system as the main energy system, with grid and district cooling as backup would make these systems redundant, so the investment and operating and maintenance (O\&M) costs of these backup systems (approximately 480000 EUR and $27600 \mathrm{EUR} / \mathrm{year}$ for the diesel generators and $120000 \mathrm{EUR}$ and $6000 \mathrm{EUR} / \mathrm{year}$ for the backup cooling), is assigned as savings from capital and O\&M costs.

Natural gas prices used in the study are taken from Statistics Sweden's web site for the first half of 2014 for industrial customers with a natural gas consumption between $30000 \mathrm{MWh}$ and $300000 \mathrm{MWh}$ [38]. For the electricity and cooling prices, the unit prices PDC is paying to grid and district cooling are used [37].

All data for the FC-CCHP system is based on DFC3000 model of FuelCell Energy $[39,40]$. DFC 3000 is a $2.8 \mathrm{MW}_{\mathrm{el}}$, MCFC-based co-generation system that uses natural gas as fuel. The FC stack lifetime and O\&M costs depend on many factors. For the purpose of this study stack lifetime is taken as 5 years and O\&M costs are taken as $30 \mathrm{EUR} / \mathrm{MW} \mathrm{h} \mathrm{h}_{\mathrm{el}}$ [40]. The DFC3000 is coupled with a double effect absorption chiller from Thermax, with a cooling capacity of $1400 \mathrm{~kW}$, coefficient of performance of 1.3 and a chilled water temperature of $6-7^{\circ} \mathrm{C}[41,42]$. The exhaust gas after the absorption cycle delivers $360 \mathrm{~kW}$ in form of water at $50^{\circ} \mathrm{C}$ [43]. Chilled water from the absorption cycle is used to cool the air to a maximum of $16^{\circ} \mathrm{C}$; the air then fed into the encapsulated cooling system of the data centre to cool the super computers. For currency conversions, the yearly average for 2014 is used [44].

The air coming out of the encapsulated cooling system has a temperature of $35-45^{\circ} \mathrm{C}$, depending on the load on the super computers and this heat is currently used in another building. Romero et al. estimated a $430 \mathrm{MWh}$ saving from recovered heat over the cold winter months [45]. This corresponds to approximately 30000 EUR/year saving in heating bills.

Economic calculations were done by Equivalent Annual Cash Flow (EACF) using the following equations [46]:

$\mathrm{EACF}=\frac{\mathrm{NPV}}{A_{l, i}}$,

$\operatorname{NPV}(i, l)=\sum_{t=0}^{l} \frac{R_{t}}{(1+i)^{t}}$,

$A_{l, i}=\frac{1-1 /(1+i)^{l}}{i}$,

where NPV is Net Present Value, $A$ is the present value of the annuity factor, $l$ is expected lifetime, $i$ is interest rate (taken as $6 \%$ for this study), $t$ is period, and $R_{t}$ is cash flow (income-expenses) for the given period.

EACF (EUR/year) is a method that gives annual benefit or loss status by incorporating one-time costs such as capital cost, large
Table 1

Input data.

\begin{tabular}{ll}
\hline Capital cost & $9520000 \mathrm{EUR}$ \\
\hline O\&M costs & $30 \mathrm{EUR} / \mathrm{MWh}$ \\
Power load & $1185 \mathrm{~kW}$ \\
Cooling load & $1282 \mathrm{~kW}$ \\
Electricity price & $108 \mathrm{EUR} / \mathrm{MWh}$ \\
Cooling price & $61.2 \mathrm{EUR} / \mathrm{MWh}$ \\
Heating price & $97.2 \mathrm{EUR} / \mathrm{MWh}$ \\
Natural gas price & $45.6 \mathrm{EUR} / \mathrm{MWh}$ \\
Interest rate & $6 \%$ \\
\hline
\end{tabular}

part changes, and interest rate. Table 1 shows the input data used in the calculations.

\section{Results and discussion}

The system saves around 815000 EUR/year in the running costs - electricity, cooling, heating bills and maintenance of backup systems - of PDC. However, considering the capital cost the system has an equivalent annual loss of approximately 317000 EUR, which means that with the current energy prices and state of technology the investment is not feasible.

The World Bank commodities price forecast shows a $1.2 \%$ average drop for the natural gas price in Europe in the coming ten years [47]. In the scenarios in the European Union's report on EU Energy Trends for 2030, it is estimated that there will be a yearly average of $5 \%$ rise in industrial electricity prices [48]. Assuming no change in natural gas price, $3 \%$ rise in electricity price, $2 \%$ yearly rise in cooling and heating prices and in O\&M costs, the system becomes feasible giving an EACF of approximately 428000 EUR/year.

Due to the FC's high power-to-heat ratio to meet the cooling demand, more electricity should be generated than needed by PDC. There are two options for the extra electricity generated. It may be directed to the conventional electrical cooling system and thereby decrease the cooling load. The optimal ratio of electrical cooling to CCHP cooling is achieved at around 1:10. The other alternative for this extra electricity is to use it on the university campus and consider it as savings, which is the original scenario. Economically, the latter is the better option by approximately $83000 \mathrm{EUR} / \mathrm{year}$ in EACF. It is also possible to set the operation mode of FC-CCHP to meet the power load of the data centre, meaning that the system should generate as much power as used at the centre, and supplement extra cooling need from district cooling. Meeting the power load also ends up being more expensive than using the extra electricity on campus; an extra loss of 430000 EUR/year.

The Next generation FCs are expected to have 7 years stack lifetime. When this is taken into account, the EACF increases to -186000 EUR/year. FuelCell Energy Solutions GmbH offers a 10 year warranty to customers that includes the first FC stack change. If the lifetime projection for the next generation FCs and this 10 years warranty are included in the calculations, the EACF comes up to a more agreeable loss of approximately 94000 EUR/year.

The above discussed results, summarised in Table 2, are sensitive to changes in energy prices; $1 \%$ yearly change on natural gas and electricity prices brings a change of 50\% and 56\% in EACF,

Table 2

EACFs of different scenarios.

\begin{tabular}{ll} 
Scenario & EACF \\
\hline Original scenario & -317000 EUR/year \\
Energy price projections & +428000 EUR/year \\
Extra El. used for cooling & -400000 EUR/year \\
Power load mode & -745000 EUR/year \\
7 Years stack lifetime & -186000 EUR/year \\
FuelCell energy deal & -94000 EUR/year \\
\hline
\end{tabular}


respectively. That means the $\mathrm{FC}-\mathrm{CCHP}$ might become feasible in case of a substantial rise in electricity price.

\section{Conclusions}

The system is far from being economically feasible due to its high capital and O\&M costs and the low lifetime of FC stacks. However, improvement in the technology with continuous research is expected to increase the lifetime of FC stacks to a satisfactory level and make FC systems more interesting, making mass production probable in the near future. This will in turn bring a broader market and economies of scale, decreasing the capital cost as well as increasing the number of skilled personnel, thereby possibly lowering the O\&M cost.

Due to its high electrical efficiency FCs are good prime movers for multi-generation systems when there is not enough heating and/or cooling demand in relation to the electrical demand. However in the data centre case, the high cooling load renders high electrical efficiency nonessential; a prime mover with a lower power-to-heat ratio may still be compatible for a CCHP meeting the energy needs of such a centre. Nonetheless, especially low noise and emission advantages still make FCs front runners as prime movers for such applications.

The considerable increase in availability of power and cooling systems by using a FC-CCHP system as the main energy system with grid and district cooling as backup, brings a different perspective to the economic feasibility of such systems. Considering the value of the data stored in the cloud servers of such systems and the scientific studies using the super computers, a loss of a certain amount money can be justified as cost of availability.

With expected changes in electricity and natural gas prices the system will be feasible. Considering the expected changes in energy prices, savings due to recovered heat from racks and absorption cycle and possible governmental subsidies and sustainability incentives on taxes, FC-CCHP for data centres would be a feasible investment.

The results of this study suggest that the focus of future research should be on fuel cell stack lifetime. The two years extension of lifetime in the next generation MCFC stacks bring an extra saving of $130000 \mathrm{EUR} / \mathrm{year}$ in the system investigated. On top of the economic impacts such improvements on lifetime would have indirect impact on market size and overall investment in the field, thus growing overall adoption of fuel cells.

\section{Acknowledgements}

The authors wish to thank to Gert Svensson [37], Henning Sloth [42], Bengt Ridell [49], Klaus Ullrich [43] and Martin Ohmer [40] for their valuable input and help during the data collection phase.

\section{References}

[1] R. Brown, E. Masanet, B. Nordman, B. Tschudi, A. Shehabi, J. Stanley, et al., Report to Congress on Server and Data Center Energy Efficiency: Public Law 109-431., Environmental Energy Technologies Division, Ernest Orlando Lawrence Berkeley National Laboratory, University of California, Berkeley, CA, 2007 (August 2).

[2] J.G. Koomey, Worldwide electricity used in data centers, Environ. Res. Lett. 3 (2008) 3.

[3] U.S. Energy Information Administration, Annual Energy Review 2011, U.S. Energy Information Administration, Washington, DC, 2012 (September 27).

[4] Uptime Institute, Opinion of the Institute: Clean, Computing, Uptime Institute, New York, NY, 2009, https://connect.ufl.edu/cns/DCO/ecdc/ECDC\% 20Construction\%20Project/Whitepapers/Uptime\%20Institute\%200pinion\%20\%20Clean\%20Computing\%20\%28Uptime\%20Inst\%29.pdf.

[5] J.G. Koomey, Estimating Total Power Consumption by Servers in the US and the World, Analytics Press, Oakland, CA, 2007.

[6] E.R. Masanet, R.E. Brown, A. Shehabi, J.G. Koomey, B. Nordman, Estimating the energy use and efficiency potential of U.S. data centers, Proc. IEEE 99 (2011) $1440-1453$.
[7] D. Xu, M. Qu, Energy environmental, and economic evaluation of a CCHP system for a data center based on operational data, Energy Build. 67 (2013) $176-186$.

[8] G. Chicco, P. Mancarefla, Distributed multi-generation: a comprehensive view, Renewable Sustainable Energy Rev. 13 (2009) 535-551.

[9] G. Pepermans, J. Driesen, D. Haeseldonckx, R. Belmans, W. D’haeseleer, Distributed generation: definition, benefits and issues, Energy Policy 33 (2005) 787-798.

[10] OECD/IEA, Distributed Generation in Liberalised Electricity Markets, International Energy Agency (IEA), Paris, France, 2002.

[11] J. Deng, R.Z. Wang, G.Y. Han, A review of thermally activated cooling technologies for combined cooling, heating and power systems, Prog. Energy Combust. Sci. 37 (2011) 172-203.

[12] T. Kerr, Combined Heat and Power: Evaluating the Benefits of Greater Global Investment, International Energy Agency, Paris, 2008.

[13] D.W. Wu, R.Z. Wang, Combined cooling, heating and power: a review, Prog. Energy Combust. Sci. 32 (2006) 459-495.

[14] R. McFarlane, Why Your Data Center Might Need a Fuel Cell Generator, TechTarget, 2014, 〈http://searchdatacenter.techtarget.com/feature/ TechWatch-Why-your-data-center-needs-a-fuel-cell-generator) (November 17).

[15] J. Mick, Microsoft's New Fuel Cell Partner is Ready to Blow Away the Bloom Box, DailyTech, June 2014, 〈http://www.dailytech.com/Microsofts+New+Fuel+ Cell+Partner+is+Ready+to+Blow+Away+the+Bloom+Box/article36118.htm $)$.

[16] A.D. Hawkes, D.J.L. Brett, N.P. Brandon, Role of fuel cell based micro-cogeneration in low carbon heating, Proc. Inst. Mech. Eng. A: J. Power Energy 225 (2011) 198-207.

[17] U. Eicker, Solar Technologies for Buildings, John Wiley \& Sons Ltd, Chichester, West Sussex, 2006.

[18] J.F. Karlsson, B. Moshfegh, Investigation of indoor climate and power usage in a data center, Energy Build. 37 (2005) 1075-1083.

[19] H.S. Sun, S.E. Lee, Case study of data centers' energy performance, Energy Build. 38 (2006) 522-533.

[20] L. Ardito, M. Morisio, Green IT-available data and guidelines for reducing energy consumption in IT systems, Sustainable Comput.: Inf. Syst. 4 (2014) 24-32.

[21] K. Ebrahimi, G.F. Jones, A.S. Fleischer, A review of data center cooling technology, operating conditions and the corresponding low-grade waste heat recovery opportunities, Renewable Sustainable Energy Rev. 31 (2014) 622-638.

[22] M.S. Todorovic, J.T. Kim, Data centre's energy efficiency optimization and greening-case study methodology and R\&D needs, Energy Build. 85 (2014) 564-578.

[23] B. Whitehead, D. Andrews, A. Shah, G. Maidment, Assessing the environmental impact of data centres Part 1: Background, energy use and metrics, Build. Environ. 82 (2014) 151-159.

[24] H. Zhang, S. Shao, H. Xu, H. Zou, C. Tian, Free cooling of data centers: a review, Renewable Sustainable Energy Rev. 35 (2014) 171-182.

[25] E. Oró, V. Depoorter, A. Garcia, J. Salom, Energy efficiency and renewable energy integration in data centres. Strategies and modelling review, Renewable Sustainable Energy Rev. 42 (2015) 429-445.

[26] R. Schmidt, M. Iyengar, J. Steffes, V. Lund, Asme. Co-generation-Grid Independent Power and Cooling for a Data Center. Ipack 2009: Proceedings of the ASME Interpack Conference 2009, vol. 2, Amer Soc Mechanical Engineers, New York, NY, 2010, pp. 1063-1075.

[27] Microsoft looks at fuel cell power in data centres via server rack, Fuel Cells Bull. 2013 (2013) 10.

[28] Fuji fuel cell operating at Frankfurt data centre, Fuel Cells Bull. 2013 (2013) 1.

[29] eBay turns on first fuel cell powered data centre, has Bloom tech, Fuel Cells Bull. 2013 (2013) 3-4.

[30] Apple doubles fuel cell capacity at NC. data centre with, Bloom, Fuel Cells Bull. 2013 (2013) 5

[31] Verizon adds Bloom fuel cell units at three facilities in California, Fuel Cells Bull. 2013 (2013) 7.

[32] F. Hagstotz, Permanent premium power for data centers-the fuel cell power station type HotModule (R), in: Intelec 2007-29th International Telecommunications Energy Conference, 2007, pp. 11-14.

[33] A.C. Riekstin, S. James, A. Kansal, J. Liu, E. Peterson, No more electrical infrastructure: towards fuel cell powered data centers, SIGOPS Oper. Syst. Rev. 48 (2014) 39-43.

[34] L. Zhao, J. Brouwer, S. James, E. Peterson, J. Siegler, A. Kansal, et al., Servers Powered By a 10 kW In-rack Proton Exchange Membrane Fuel Cell System. ASME 2014 8th International Conference on Energy Sustainability \& 12th Fuel Cell Science Engineering and Technology Conference, ASME, Boston, MA, 2014.

[35] L. Zhao, J. Brouwer, J. Liu, S. James, J. Siegler, A. Kansal, E. Peterson, Fuel Cells for Data Centers: Power Generation Inches From the Server, in: Microsoft Research Technical Report MSR-TR-2014-37, 2014.

[36] G.L. Guizzi, M. Manno, Fuel cell-based cogeneration system covering data centers' energy needs, Energy 41 (2012) 56-64.

[37] Svensson GA. Deputy Director PDC-HPC at KTH. Personal Communication January 8, 2014.

[38] Energipriser på naturgas och el: Statistiska Centralbyrån (SCB), Stockholm Swed Statistiska Centralbyrån, October, 2014, 〈http://www.scb.se/sv_/ 
Hitta-statistik/Statistik-efter-amne/Energi/Prisutvecklingen-inomenergiomradet/Energipriser-pa-naturgas-och-el/>.

[39] FuelCell Energy, Inc, 2.8 MW., DFC3000, FuelCell Energy, Inc, Connecticut, USA, January, 2014, 〈http://www.fuelcellenergy.com/products-services/ products/2-8-mw-dfc3000/〉.

[40] Ohmer M.Business Development at FuelCell Energy Personal Communication October 142014

[41] Thermax Sustainable Solutions Energy \& Environment, Thermax Europe | Products | Exhaust Gas Fired Chiller | Specification Sheet | Exhaust Gas Fired, Thermax Sustainable Solutions Energy \& Environment, Milton Keynes, United Kingdom, October, 2014, 〈http://www.thermax-europe.com/exhaust-gasfired-spec.aspx $\rangle$.

[42] Sloth H., Director at SEG A/S, Personal Communication July 11, 2014.

[43] Ullrich K., Director Business Development at FuelCell Energy, Personal Communication December 03, 2014.
[44] Yearly Average Exchange Rates-Oz Forex Foreign Exchange, 〈http://www. ozforex.com.au/forex-tools/historical-rate-tools/yearly-average-rates September 15, 2011

[45] M. Romero, H. Hasselqvist, G. Svensson, Supercomputers keeping people warm in the winter, in: 2nd International Conference on ICT for Sustainability, Stockholm, Sweden, 2014.

[46] R.A. Brealey, S.C. Myers, F. Allen, Principles of Corporate Finance, McGraw-Hill/Irwin, New York, NY, 2011.

[47] J. Baffes, D. Cosic, Commodity markets outlook, in: Global Economic Prospects, World Bank, Washington, DC, October 2014.

[48] P. Capros, L. Mantzos, N. Tasios, A.D. Vita, N. Kouvaritakis, EU Energy Trends to 2030: 2009 Update, Publications Office of the European Union, Luxembourg, 2010.

[49] Ridell B., Senior Consultant at Grontmij A.B., Personal Communication October 27, 2014. 